\title{
Evaluation of Bio- efficacy and Phytotoxicity of Thiophenate Methyl 450g/l + Pyreclostrobin 50g/l (Xelora 500g/l FS) against Dry Root Rot of Chickpea
}

\author{
V. R. Kulkarni* and S. A. Ashtaputre \\ Department of Plant Pathology, College of Agriculture, Dharwad University of Agricultural \\ Sciences, Dharwad-580005, Karnataka, India \\ *Corresponding author
}

\begin{tabular}{l} 
Ke y w or d s \\
Bio- efficacy, \\
Phytotoxicity, \\
Chickpea, \\
Pyraclostrobin \\
\hline Article Info \\
\hline $\begin{array}{l}\text { Accepted: } \\
15 \text { December } 2019 \\
\text { Available Online: } \\
\text { 20 January } 2020\end{array}$ \\
\hline
\end{tabular}

Keywords

Bio- efficacy, Phytotoxicity, Chickpea, Article Info

Accepted: Available Online: 20 January 2020

\section{A B S T R A C T}

Chickpea, (Cicer arietinum L.) is one of the most important pulse crops of India, which belongs to family Fabaceae. It occupies very important position in semiarid farming system both for human nutrition and restoring the soil fertility. Occurrence of dry root rot caused by Rhizoctonia bataticola (Taub.) Butler is emerging as a serious biotic constraint in recent years for successful and profitable cultivation of chickpea the efficacy of various fungicides viz. Thiophenate methyl 450g/l + Pyreclostrobin 50g/l (xelora 500g/l FS), Thiophenate methyl 50\%WP, Pyraclostrobin 20WG, and Carbendazim 50\% WP as seed treatment and soil application were evaluated against Rhizoctonia bataticola causing root rot disease of Chickpea. Management study of root rot disease of chickpea done under field conditions for two years. significantly lower incidence of root rot and wilt (6\%) and higher yield (6.76 q/ha) was recorded in $\mathrm{T}_{3}$ (Seed treatment with Thiophenate methyl 450g/l + Pyraclostrobin 50g/l FS @ 4ml/kg of seed), which was on par with the $\mathrm{T}_{4}$ (Seed treatment with Thiophenate methyl 450g/l + Pyraclostrobin $50 \mathrm{~g} / \mathrm{l}$ foliar spray @ 5ml $/ \mathrm{kg}$ of seed) by showing per cent disease incidence of 6.3 and yield of $6.75 \mathrm{q} / \mathrm{ha}$. Whereas, $\mathrm{T}_{7}$ (Seed treatment with Carbendazim 50\%WP @ $3 \mathrm{ml} / \mathrm{kg}$ ) was found least effective by showing per cent incidence of 12.90 and yield of $5.7 \mathrm{q} / \mathrm{ha}$ among the treatments. Maximum incidence of root rot and wilt $(21.90 \%)$ and lowest yield (5.12q/ha) recorded in untreated control.

\section{Introduction}

Chickpea, (Cicer arietinum L.) is one of the most important pulse crops of India, which belongs to family Fabaceae. It occupies very important position in semi-arid farming system both for human nutrition and restoring the soil fertility (Singh and Sirohi, 2003). Chickpea is the premier pulse crop of India, grown all over the country mainly Madhya Pradesh, Rajasthan, Uttar Pradesh, Maharashtra, Karnataka and Haryana states in Rabi season. India contributes the major share to the global chickpea area and production 
(both about 65\%). In India, it is grown on 9.62 mha area with a production of $9.37 \mathrm{mt}$ and productivity of $974 \mathrm{~kg} / \mathrm{ha}$ (Pocket book of agricultural statistics, 2017).

Chickpea productivity often remains low due to susceptibility of the crop to different biotic and abiotic stresses. Among the biotic stresses, diseases, insect pests, nematodes and parasitic weeds account for major losses. The crop is attacked by 172 pathogens which include 67 fungi, 22 viruses, 3 bacteria, 80 nematodes and phytoplasma from all over the world (Nene et al., 1996). Among the diseases dry root rot caused by Rhizoctonia bataticola (Taub.) Butler (pycnidial stage: Macrophomina phaseolina Tassi Goid) is emerging as serious threat to the chickpea growing regions of India (Masood and Shivkumar, 2001). The pathogen survives in soil on infected host debris. Secondary spread of the disease is through farm implements, irrigation water and rain splashs (Pande et al., 2010). Being soil borne in nature, it is very difficult to control this pathogen. Yield losses due to root rot are more when the conditions are congineal for disease development. Losses to the extent of 70.8 per cent at full podding and 48.9 per cent at preharvest stage of the crop have been reported due to the disease (Ahmed and Mohamad, 1986). It is both soil and seed borne and infects plants mainly from flowering stage to maturity. The disease is reported to be more severe when chickpea crop is exposed to moisture stress conditions (Sharma et al., 2010)

Considering the importance of the diseases and crop the present investigation was carried out for the management of diseases through systemic and combi products.

\section{Materials and Methods}

A field experiment was undertaken to study the efficacy of various fungicides as seed treatment for the management of dry root rot with a variety Annigeri 1(A1). The study was conducted at Agriculture Research Station, Dharwad during two consecutive years in the rabi 2015-16 and 2016-17 in Randomized Block Design with eight treatments along with three replications. The crop was sown with $30 \times 10 \mathrm{~cm}$ spacing and with net plot size of $1.8 \times 3.0 \mathrm{~m}$. The chemicals used in the present investigation were Thiophenate methyl 450g/l + Pyreclostrobin 50g/l (xelora $500 \mathrm{~g} / \mathrm{l}$ FS), Thiophenate methyl 50\%WP, Pyraclostrobin 20WG, and Carbendazim 50\% WP.

The seeds of chickpea variety treated with Thiophenate methyl 450g/l + Pyreclostrobin $50 \mathrm{~g} / \mathrm{l}$ (xelora 500g/l FS) at four different concentrations $(2 \mathrm{ml} / \mathrm{kg}, 3 \mathrm{ml} / \mathrm{kg}, 4 \mathrm{ml} / \mathrm{kg}$ and $5 \mathrm{ml} / \mathrm{kg}$ of seeds) Thiophenate methyl $50 \% \mathrm{WP}$ $(2 \mathrm{ml} / \mathrm{kg}$ of seeds), Pyraclostrobin 20WG $(0.75 \mathrm{ml} / \mathrm{kg}$ of seeds) and Carbendazim $50 \% \mathrm{WP}(3 \mathrm{ml} / \mathrm{kg}$ of seeds). The observations were recorded on root rot incidence prior to harvest were recorded and done statistically analysed and also taken chickpea yield data.

The root rot incidence $(\%)$ in each treatment was calculated using following formula.

Root rot incidence $(\%)=$

$$
\stackrel{\text { No. of diseased plants }}{\times 100}
$$

Total No. of plants observed

\section{Results and Discussion}

All the treatments significantly checked the root rot and wilt incidence over untreated control during both the years 2015-16 and 2016-17 (Table 1). The pooled data of the year 2015-16 and 2016-17 for the management of root rot and wilt disease of chickpea revealed that, significantly lower incidence of root rot and wilt (6\%) and higher yield $\left(6.76 \mathrm{q} / \mathrm{ha}\right.$ ) was recorded in $\mathrm{T}_{3}$ (Seed 
treatment with Thiophenate methyl $450 \mathrm{~g} / \mathrm{l}+$ Pyraclostrobin 50g/l FS @ 4ml $/ \mathrm{kg}$ of seed), which was on par with the $\mathrm{T}_{4}$ (Seed treatment with Thiophenate methyl $450 \mathrm{~g} / \mathrm{l}+$ Pyraclostrobin 50g/l foliar spray @ 5ml/kg of seed) by showing per cent disease incidence of 6.3 and yield of $6.75 \mathrm{q} / \mathrm{ha}$. Whereas, $\mathrm{T}_{7}$ (Seed treatment with Carbendazim 50\%WP @ $3 \mathrm{ml} / \mathrm{kg}$ ) was found least effective by showing per cent incidence of 12.90 and yield of $5.7 \mathrm{q} / \mathrm{ha}$ among the treatments. Maximum incidence of root rot and wilt $(21.90 \%)$ and lowest yield $(5.12 \mathrm{q} / \mathrm{ha})$ recorded in untreated control (Table 1and 2).

Sharma and Munju kumari (2017) Seed treatment with Carbendazim was proved most effective in minimizing the disease as well as pathogen population in soil followed by thiophenate methyl. The Carbendazim and Thiophanate-methyl, followed by Aliette and Nativo were more effective in reducing the impact of pathogen as well as enhancing the plant growth in greenhouse experiment (Maitlo et al., 2014). The results similarly found by Singh et al., (1993), Singh and Sindhan (1998) and Khan et al., (2012). The general mode of action of systemic fungicides is associated with interference with the electron transport chain influencing the energy budget of cell, reduction in the biosynthesis of new cell materiel required for growth and development of the organism and disruption of cell structure and permeability of cell membrane (Ravichandran and Yashoda R. Hegde, 2017. Management of dry root rot of chickpea caused by Rhizoctonia bataticola through fungicides.)

Table.1 Reaction of Thiophenate methyl 450g/l + Pyreclostrobin 50g/l (xelora 500g/l FS) against dryroot rot of chickpea on disease incidence

\begin{tabular}{|c|c|c|c|c|c|c|}
\hline \multirow{2}{*}{$\begin{array}{l}\text { Tr. } \\
\text { No }\end{array}$} & \multirow[t]{2}{*}{ Treatments } & \multirow{2}{*}{$\begin{array}{l}\text { Dosage /ha } \\
\text { Formulation } \\
\text { (ml/kg seeds) }\end{array}$} & \multicolumn{2}{|l|}{ PDI } & \multirow[t]{2}{*}{ Pooled } & \multirow{2}{*}{$\begin{array}{l}\text { Disease } \\
\text { reduction } \\
\text { over } \\
\text { control }(\%)\end{array}$} \\
\hline & & & $2015-16$ & 2016-17 & & \\
\hline 1. & $\begin{array}{l}\text { Thiophenate methyl } 450 \mathrm{~g} / \mathrm{l}+ \\
\text { Pyraclostrobin 50g/l FS }\end{array}$ & 2.0 & $\begin{array}{l}12.40 \\
(20.62)^{*}\end{array}$ & $\begin{array}{l}8.65 \\
(17.11)\end{array}$ & $\begin{array}{l}10.50 \\
(18.86)\end{array}$ & 52.04 \\
\hline 2. & $\begin{array}{l}\text { Thiophenate methyl } 450 \mathrm{~g} / \mathrm{l}+ \\
\text { Pyraclostrobin 50g/l FS }\end{array}$ & 3.0 & $\begin{array}{l}7.90 \\
(16.30)\end{array}$ & $\begin{array}{l}6.23 \\
(14.45)\end{array}$ & $\begin{array}{l}7.00 \\
(15.37)\end{array}$ & 68.04 \\
\hline 3 & $\begin{array}{l}\text { Thiophenate methyl 450g/l + } \\
\text { Pyraclostrobin 50g/l FS }\end{array}$ & 4.0 & $\begin{array}{l}6.20 \\
(14.42)\end{array}$ & $\begin{array}{l}5.72 \\
(13.85)\end{array}$ & $\begin{array}{l}6.00 \\
(14.13)\end{array}$ & 72.60 \\
\hline 4 & $\begin{array}{l}\text { Thiophenate methyl } 450 \mathrm{~g} / 1+ \\
\text { Pyraclostrobin 50g/1 FS }\end{array}$ & 5.0 & $\begin{array}{l}6.60 \\
(14.81)\end{array}$ & $\begin{array}{l}6.00 \\
(14.19)\end{array}$ & $\begin{array}{l}6.30 \\
(14.50)\end{array}$ & 71.23 \\
\hline 5 & Thiophenate methyl 50\% WP & 2.0 & $\begin{array}{l}10.40 \\
(18.82)\end{array}$ & $\begin{array}{l}7.11 \\
(15.48)\end{array}$ & $\begin{array}{l}8.70 \\
(17.15)\end{array}$ & 60.27 \\
\hline 6 & Pyraclostrobin $20 \mathrm{WG}$ & 0.75 & $\begin{array}{l}9.30 \\
(17.73)\end{array}$ & $\begin{array}{l}7.04 \\
(15.39)\end{array}$ & $\begin{array}{l}8.10 \\
(16.56)\end{array}$ & 63.01 \\
\hline 7 & Carbendazim 50\% WP & 3.0 & $\begin{array}{l}17.80 \\
(24.96)\end{array}$ & $\begin{array}{l}8.71 \\
(17.16)\end{array}$ & $\begin{array}{l}12.90 \\
(21.06)\end{array}$ & 41.10 \\
\hline 8 & Untreated control & & $\begin{array}{l}26.00 \\
(30.68)\end{array}$ & $\begin{array}{l}17.95 \\
(25.07)\end{array}$ & $\begin{array}{l}21.90 \\
(27.88)\end{array}$ & -- \\
\hline \multicolumn{3}{|c|}{ 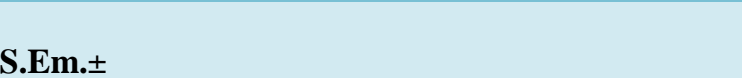 } & 0.45 & 0.35 & 1.21 & -- \\
\hline \multicolumn{3}{|c|}{ CD@ 5\% } & 1.38 & 1.07 & 3.69 & -- \\
\hline
\end{tabular}

* Arcsine transformed values. 
Table.2 Reaction of Thiophenate methyl 450g/l + Pyreclostrobin 50g/l (xelora 500g/l FS) against root rot of chickpea on yield

\begin{tabular}{|c|c|c|c|c|c|c|}
\hline \multirow{2}{*}{$\begin{array}{l}\text { Tr. } \\
\text { No }\end{array}$} & \multirow[t]{2}{*}{ Treatments } & \multirow{2}{*}{$\begin{array}{l}\text { Dosage /ha } \\
\text { Formulation } \\
\text { (ml/kg seeds) }\end{array}$} & \multicolumn{2}{|c|}{ Yield (kg/ha) } & \multirow[t]{2}{*}{ Pooled } & \multirow{2}{*}{$\begin{array}{l}\text { Increase in yield } \\
\text { over control }(\%)\end{array}$} \\
\hline & & & $2015-16$ & 2016-17 & & \\
\hline 1. & $\begin{array}{l}\text { Thiophenate methyl } 450 \mathrm{~g} / \mathrm{l}+ \\
\text { Pyraclostrobin 50g/l FS }\end{array}$ & 2.0 & 6.53 & 7.00 & 5.92 & 4.78 \\
\hline 2. & $\begin{array}{l}\text { Thiophenate methyl 450g/l + } \\
\text { Pyraclostrobin 50g/l FS }\end{array}$ & 3.0 & 7.17 & 7.20 & 6.49 & 14.86 \\
\hline 3 & $\begin{array}{l}\text { Thiophenate methyl } 450 \mathrm{~g} / 1+ \\
\text { Pyraclostrobin 50g/l FS }\end{array}$ & 4.0 & 8.10 & 7.38 & 6.76 & 19.64 \\
\hline 4 & $\begin{array}{l}\text { Thiophenate methyl 450g/l + } \\
\text { Pyraclostrobin 50g/l FS }\end{array}$ & 5.0 & 8.00 & 7.30 & 6.75 & 19.46 \\
\hline 5 & Thiophenate methyl 50\% WP & 2.0 & 7.47 & 6.98 & 6.45 & 14.15 \\
\hline 6 & Pyraclostrobin $20 \mathrm{WG}$ & 0.75 & 7.77 & 7.03 & 6.62 & 17.16 \\
\hline 7 & Carbendazim 50\% WP & 3.0 & 6.50 & 6.07 & 5.70 & 0.88 \\
\hline 8 & Untreated control & & 5.93 & 5.80 & 5.65 & -- \\
\hline \multicolumn{3}{|c|}{ S.Em. \pm} & 0.10 & 0.13 & 0.20 & -- \\
\hline \multicolumn{3}{|c|}{ CD@ $@ 5 \%$} & 0.32 & 0.39 & 0.62 & -- \\
\hline
\end{tabular}

\section{References}

Ahmed, Q. and Mohammad, A. (1986). Losses in yield due to Rhizoctonia root rot of chickpea in Bihar. Indian Phytopath.; 39: 590-592.

Khan RA, Bha TA, Kumar K.2012., Management of Chickpea (Cicer arietinum L.) Dry root Rot Caused by Rhizoctonia bataticola (Taub.) Butler. International Journal of Research in Pharmaceutical and Biomedical sciences. vol. 2012; 3(4): 1539-1548.

Mailto S.A., Syed R.N., Rustamani M.A., Kuhro R.D and Lodhi A.M. 2014. Comparative efficacy of different fungicides against fusarium wilt of chickpea (Cicer arietinum L.) Pakistan journal of botany; 46(6): 2305-2312.

Masood, A. and Shivkumar. (2001). An overview of chickpea research in India. Indian J. Pulses Res. 14 (2): 81-89.

Nene, Y.L., Sheila, V. K. and Sharma, S. B. (1996).A World list of chickpea and pigeonpea pathogens. ICRISAT, 5thedition.Pp. 1-27.

Pande, S., Desai, S. and Sharma, M. (2010).
National Symposium On Climate Change and Rain fed Agriculture, Feb18-20: Indian Society of Dry land Agriculture and Central Research Institute for Dry land Agriculture. pp. 55-59.

Ravichandran,S. And Yashoda R. Hegde, 2017. Management of dry root rot of chickpea caused by Rhizoctonia bataticola through fungicides. Int.J.Curr.Microbiol.App.Sci1594-15600.

Sharma, M., Mangala, U.N., Krishnmurthy, M., Vedez, V. and Pande, S. 2010. Drought and dry root rot of chickpea. Paper presented in 5th International Legumes Research Conference (IFLRC5) and European Conference on Grain Legumes (AEP-7), April 26-30. Antalya, Turkey.

Sharma O.P and Manju Kumari, 2017., Management of dry root rot disease (Rhizoctonia bataticola) of chickpea through fungicides. International journal of chemical studies;5(4):45-47.

Singh A, and Sirohi A., 2003. A status of chickpea diseases in Himachal Pradesh, 
India. International Chickpea and Pigeon pea Newsletter, 2003; 10:29-31. Singh RN, Upadhyay JP, Ojha KL. 1993., Management of chickpea dry root rot by fungicide and gliocladium. J. Appli.
Bio., 46-51.

Singh R, Sindhan GS.1998., Effect of fungicides on the incidence of dry root rot and biochemical status of chickpea plants. Plant Dis. Res. 1998; 13:14-17.

\section{How to cite this article:}

Kulkarni, V. R. and Ashtaputre, S. A. 2020. Evaluation of Bio- efficacy and Phytotoxicity of Thiophenate Methyl 450g/l + Pyreclostrobin 50g/l (Xelora 500g/l FS) against Dry Root Rot of Chickpea. Int.J.Curr.Microbiol.App.Sci. 9(01): 848-852.

doi: https://doi.org/10.20546/ijcmas.2020.901.093 